\title{
Principles and Opportunities of the Study of Theatrical Heritage in the Practice of Choreographic Education
}

\author{
Tatiana Portnova
}

Art History, Choreography Art Department of Slavic Culture Institute, Art History Department of Kosygin Russian State University, Russia

Copyright $\bigcirc 2018$ by authors, all rights reserved. Authors agree that this article remains permanently open access under the terms of the Creative Commons Attribution License 4.0 International License

\begin{abstract}
This article is dedicated to an underdeveloped, but a highly relevant aspect of work of museums, first of all, the theatrical ones, namely keeping, studying and promoting the works associated with choreographic heritage. The artistic and aesthetic potential of material and visual exhibits related to the ballet theatre is revealed. All the figurative and metaphoric world of dance involved in a particular exhibition project is considered from the standpoint of the main carrier of the theatrical idea at the level of its perception by the master of the theatrical university as a potential researcher. The proposed aspect of consideration of the monuments of choreographic heritage in the museum environment raises this problem to the quantitatively new level of conceptuality, justifies the possibility of allocating the theory of their study in an independent scientific area that integrates in the modern theatre museology as a new direction of interdisciplinary knowledge and develops through the various liberal arts.
\end{abstract}

Keywords Choreographic Heritage, Theatrical Collection, Study Methodology, Museum Exhibit

\section{Introduction}

Modern museum education is aimed at enhancing the creative abilities of a person and creating a multitier system of the theatrical education. The problem of the expansion of the cultural and educational space is solved by using various sources of culture and various kinds of knowledge. These include the usage of museums in the educational process of a future choreographer as a source of cultural values, a repository of cultural standards and experience of mankind. "Museum can be called a unique result of interaction between culture and mind of a man" [31.c.15] various government programs aimed at the development of the cultural potential were reviewed during the study. $[9,10,14]$. The survey attention field of the author includes various aspects of conceptualization of the place and functions of the museum in the culture and projects implemented conceptually. [23,29,30,32,35]. Literature was analyzed on the matters of museum activities [8.19.28.34]. Among these sources, the most prominent were the works focused on the problems of the museum education. [21], [38]. For instance, G. V. Vishina regards the museum education as well as the direction of development of the system of additional education, revealing new functions of a museum teacher in a functional complex of school-museum-university [39]. S.M. Troianskaia refers to the museum as a symbol of culture: "The mission of a museum as a symbol of culture and an educational institution is to play a major part in the formation of an integral person and development of its general cultural competence" [37:20-21]. Museum education can be considered to be a factor in the formation of the social experience of a person: art enriches the life experience and museum facilitates the development of said experience and skills. Research work of students and masters isn't specified in the classification of museum education forms made by museographer O. Botiakova [3]. Speaking about the uniqueness of theatrical museum, we'd like to emphasize that the experience of personal contact with reality and actor culture of the past is exactly the main thing other institutes of civilization can't offer.

Analysis of academic literature demonstrated the lack of developed standardized methods and recommendations for research work raising the level of general cultural and professional competence of masters. The museum is seen as one of the institutions designed for storing, collecting and interpreting the objects. Based on the multicomponent structure of theatrical collections $[1,2,4,16,17$, $20,22,25,27,30,36]$ we have developed the indicators of the competences of the researcher choreographer: using specific opportunities and educational potential of museums and museum education, active teaching methods, museum items and museum environment, figurative language of exhibition and works of theatrical art. [13].

Three major issue and thematic groups are specified, forming the basis of their classification and representing the history of ballet theatre. Typology and variety of museum theatrical exhibitions demonstrating the substantial world of choreographic culture are emphasized (photographs, graphical and artistic portraits of ballet 
dancers, sculptures and figurines of the actors in roles, posters and broadsheets to the performances, theatrical masks, book editions and librettos for performances). This leads to the creation of a subjectively new artistic product providing the expression of exclusive value through the authenticity of museum exhibits. The subject field of exhibitions of specific theatre museums and possible aspects of their study are analyzed.

The purpose of the research is to analyze the artistic and aesthetic features of museum exhibits dedicated to the dance, their specific features in the context of the methods of their study by masters of choreography direction, as well as their affiliation to the artistic culture.

Methodological basis of the research is the analytical approach to understanding theatre exhibition and ballet exhibit in the context of modern conceptual methods of its study. The culturological approach used in the article allows studying museum exhibits of the ballet theme as an integral aggregate of material and spiritual realias created in the course of historical development. Moreover, the methodological basis of the research included museology theories (theory of documenting and theory of museum communication) as the fundamental elements.[7]. The research aspect of the article was implemented through the applicable empirical research of capabilities of the museum and theatrical education for the development of general cultural and professional creative competence of students. We'd like to note that the organization of research and project activities is the most effective at the undergraduate level, especially of the masters and Ph.D. programs as it stipulates possession of a certain level of experience in research searching and problematic methods of processing and analyzing the gathered information.

\section{Aspects of Studying the Choreographic Heritage in Museum Collections}

Museum items are studied using methods relevant to the branches specific to the museum: art history methods for art pieces are used; theatric history methods for theatric materials; ballet history methods for the narrower range of exhibits related to the ballet theatre. As museum historians study items not only as a source of knowledge but also as a cultural value item and a source of emotions, attractive properties of an item are taken into account as well. Studying the museum items comprises three successive stages: the attribution of objects, their classification and systematization, and later interpretation. Everything is different when talking about studying and researching the museum items by novice researchers in the field of dance.

Theatre museums can be classified in three types: general profile museums in all their entirety; museums in theaters that are more focused and has permanent exhibitions related to the history of this theater and its company; memorial museums dedicated to life and work of outstanding figures of theatrical arts (actors, directors). Exhibitions of the most famous theatre museums: A.
Bakhrushin theatre museum (Moscow), Museum of theatrical and musical culture (Saint Petersburg), Paris theatre "Grand Opera", Milan theatre "La Scala", London theatre Covent garden, the New York "Metropolitan Opera", the Museum of the State Academic Bolshoi theatre in Moscow and Mariinsky theatre in Saint Petersburg based on the spectacular nature of theatrical art with its specifics. Such museums have quite big archives storing manuscripts, plans, and directors' design works for performances demonstrating the preparatory process.

Memorial museums are more chamber ones (the House Museum of K. S. Stanislavsky, the House Museum of M. N. Ermolova, the House Museum of G. S. Ulanova, etc.). As a rule, a memorial museum represents the theatrical person in the most diverse manifestations of his character, showing the scenery where famous persons lived and worked. Exhibits of these museums become priceless over time as a rare testament to the talent of these persons, especially when many pages of the theatrical history; the visitors (theatergoers) will gladly learn these phenomena as these actors were for our culture. Collection of a theatre museum serves this important and noble task by all its imaginative informational material, all its clear structure.

As a rule, theatre museum has exhibits of documental nature. Ballet iconography is one of the most important branches of theatre history: a discipline dealing with visual material reflecting various aspects of a dance performance. Iconographic sources can answer important questions related to the history and technique of dance, questions relevant to ballet costume, questions characterizing the features of various dance schools, questions related to the relationship of dance and culture in general. Hence, the concept of the personality of the actor, and the nature of the actor's dramatic path suggests the researcher at least two main interpretations. In one case, one can speak, first and foremost, about the path of the actor or director as well as their position, credo, adopted moral, ideological and aesthetic principles; in the other case, one can speak about development (evolution) of their work.

The most used classification as of now is the classification of types of museum exhibition based on the buildup method, i.e. the order of grouping and formation of exhibition materials: systematic, ensemble or themed, with each of them having a specific conceptual field for a researcher. Based on a generalization of museumification of works of choreographic material heritage, a concept was proposed describing the formation of a creative approach to traditional and innovative methods of the buildup of exhibitions interpreted as a special cultural space designed for the future museum study.

A large selection of themes of creative works of masters of the choreographic profile lies in the source database, hence the museum's one and it needs to reflect their knowledge in a wide range of research problems, ability to reflect upon and analyze them. The moment of contact with cultural values is experienced as a significant event for a young researcher who feels a sense of belonging, participation in cultural life. It is the complicity that is not only through the event and empathy, but also through the 
promotion consisting of own creative, artistic and project activities. This is especially true for historical research. Given the dynamic nature of dance that won't be passed to descendants in its direct form, the stopped and fixed images are the only authentic sources for the study.

\section{Methods of Studying the Museum Items in Theatrical Exhibitions}

The most distinctive types of museum collections (including theatre museums) are typological, thematic or personal collections. The basis of any museum collection consists of items of the main fund. The main fund of a museum may only comprise authentic sources like material (personal belongings of the actors), documental (ballet costumes, footprints, portrait images), written (letters and manuscript evidence) etc. Things like reproduction material (porcelain figurines), replicas (masks), reconstructions (copy of blueprints), stage layouts and replays reproducing the original comprise the auxiliary scientific fund. Along with main and auxiliary scientific funds, temporary funds may be formed (items received from organizations or individuals for exhibitions, display, research etc.). A researcher may come upon all this museum material and so the problem of selection and analysis of existing information becomes exceptionally relevant.

Let's select three groups of research tasks corresponding to the structural components of their general cultural competence and directly related to the type and funds of a museum. Since the acquisition of funds for the museum must be focused depending on its profile, in turn, it determines the value of the museum item regarding its study. For instance, for a historical theatre museum, the most valuable are the items of direct relevance to the history and theatrical culture of certain ages, including the choreographical one. Within the cultural-historical method, the theater is interpreted as a product of social life and specific cultural and historical conditions. For a memorial theatrical museum important are the items related to the life and work of a particular individual. The biographical method sets the relationship between the biography of a writer and features of their literary work. Biography and personality of a theatrical figure or artist will be treated as a defining moment of work. The informational content of a source, its reliability (representativeness), visibility (attractiveness) should be taken into account when selecting items for the study. Museums existing in the theatres and choreographical educational institutions can be invaluable in providing unique materials and documents related to the history of their origin, to graduates of ballet schools and the legends of Russian ballet theatre, to performances staged at these theatres, to choreographers and artists. The historical and typological method will be the most wanted here, revealing the unity of similar but unrelated phenomena with their similarity being the result of the coincidence of conditions of development. For example, choreographers and artists working together in the same company or graduated the same year, or performances that were set on the same stage in a choreographic reconstruction of the same or different directors. When conducting research in any theatre museum, the descriptive method will be most appropriate, consistently interpreting the chosen material and systematizing it in accordance with the set research objective. When analyzing an individual performance, it is preferred to use the structural method, aiming to identify all the elements of a choreographic work and at the same time to recreate its model in general. Iconographic research method should be used in the study of art materials and photographs that are usually stored in special sections in the cabinets, folders, and shelves. They may help to learn how the ballet artists and choreographers of ages bygone looked like as well as to imagine the style and manner of dance performance. Finally, one of the main methods used in the research work is the iconological method that allows combining semiotics, origin, typology, symbolism and artistic form as well as revealing the specifics of each topic.

During the classification and systematization of museum items, it is necessary to conduct a comparative analysis of their characteristic features with other items similar or close by origin. To perform such a comparative analysis, one may use similar items from the museum, catalogs, indexes etc. General and distinctive features that are inherent to a specific museum object are revealed during the works on classification and systematization. Then the information on the item should be summarized and structured by classifying and systematizing, which in turn allows more adequately interpreting the cultural, social, historical information inherent to a theatrical museum item.

Thus, a retrospective analysis of the data obtained during the study allowed identifying the target component of the theatre museum as an educational system, which can be divided into three groups of objectives: acquisition of skills for ethic research in the museum, communication with cultural heritage, acceptance of other cultures and dialogue with them. This contributes to increasing the knowledge base in the field of choreography, stimulation of cognitive interests, and awareness of the belonging to the modern culture.

\section{Museum Education and Opportunities of Studying of Choreographic Heritage}

An empirical study of the possibilities of the museum education for the development of general cultural competence through the implementation of experimental technologies comes to the front. It seems logical and culturally congruent to use the unique educational opportunities of theatre museums as the storages of cultural references and experience of mankind for the development of common cultural competence of future theater figures. "Museum as a holistic educational system will work in the 
presence and the interaction of all structural and functional components subordinated to the overall objective of development and self-realization of a person, its belonging to the global flow of culture." [3:48]. G. V. Ganshina indicates the absence of a single methodological basis and practice-oriented technologies of joint socio-cultural activities of a university and a museum in terms of diversification of higher education. [12]. Now and in the future museums will be included in the general educational process of the period of digitization and global visualization of culture. According to B. Stolyarov, museums will become a school of “...visual and spatial thinking that attaches a person to the surrounding world through the monuments of culture and art; a space that accumulates aesthetic experience of mankind and provides the individual with the opportunity of self-identification; a filter of quality in man's relation to life and the environment in its substantive, philosophical and ethical sense" [33]. The expansion of cultural and educational space must occur through the inclusion of museums in the educational process at universities. [6], [40]. However, even such traditional museum activities as guided tours, didactic and creative exhibitions, and museum electives are not always used these days. "The first historically established forms of the museum and educational activities are lectures, guided tours and consultations, in which the museum item (museum exhibition) is an integral part of the museum and educational process" [11:147]. Three main forms of the educational process: lessons in a museum exhibition, classroom and practical lessons should be supplemented by applying a systematic approach with target definition, structuring the content, choice of methods, means and forms presented in the schematic design of the experimental technology. Appeal to cultural standards is expedient in practical tasks, including creative design already at the stage of undergraduate courses of bachelor's degree and final thesis papers. Already on this initial level, abilities of emotional perception, dialogic interaction in the process of communication with cultural values through the museum communication are formed. Educationally expedient usage of the museum environment contributes to immersion in a certain era, reliving the historical situations, updating the associative links, coexisting and participating, and belonging to the cultural stream. Especially effective is the multi-sensory impact when the visual perception is reinforced by the guide's speech, music, tactile and olfactory sensations, and employing interactive exhibits. Experimental work with students at the premises of universities is relevant at the masters' stage. Museums can become the main bridge between the first and the advanced research level of work on the dissertation project, between the modernity and the past, between a man and the cultural heritage.

\section{Conclusions}

Thus, considering the foregoing, iconographic, decorative and other material stored in collections and displayed in the exhibitions of theatre museums can be an important source for the study of the choreographic heritage. Theoretically explaining the meaning and purpose of a museum not only as a source of storage of exhibits and desobjectivation of cultural values but also as means for the development of research abilities, we identified and used the educational potential of a museum and museum education. Unfortunately, the distinctive feature of modern museums from the traditional ones is the change of priorities, when the focus is set more on the entertainment aspect and working with mass visitors without reference to their education level. However, the analysis of existing creative works of students and research papers by masters also allows making a conclusion about the positive impact of experimental education on the implementation of abilities determining the development of general cultural competence with the means of museum theatrical education. The innovation processes going in the art have an impact on the methods of their study as well. [15]. The methodology of studying the museum items with theater context presented in this article, as well as technology of development of general cultural and professional competence can be used by university professors and museum teachers in performing their project and educational activity and is recommended to students who undertook highly specialized courses and masters who are preparing their research studies on choreography. The research results can be used when leading highly specialized courses in the system of training and retraining of teachers for various educational systems.

\section{REFERENCES}

[1] Bakhrushin, A. (2002). State Central Theatre Museum (Moscow). Guide to the manuscript fund of the A. Bakhrushin State Central Theatre Museum / Ministry of Culture of the Russian Federation [comp. and ed. I. S. Preobrazhenskaia]. - M.: A.A. Bakhrushin State Central Theatre Museum, $415 \mathrm{p}$.

[2] Baudin,. K. (2010). Museum Ludwig | Koln. / Wallraf-Richartz-Jahrbuch, Vol. 71, P. 16-22

[3] Botiakova, O.A. (2006). Ethnographic museum in the context of education and culture of Russia: a dissertation abstract / Saint Petersburg State University, 30 p.

[4] Breakthrough. Russian theater and decorative art 1870-1930: [catalogue of the exhibition in 2 parts] / A.A. Bakhrushin State Central Theatre Museum; [compilators: D. V. Rodionov, S. G. Djafarova]. - Moscow: A.A. Bakhrushin State Central Theatre Museum, 399 p.

[5] Brida. T. (1990). 1 From the Guest Editor / The Journal of Museum Education, Vol. 15, No. 2, Museum Theater (Spring-Summer), p. 3.

[6] Conn,. S. (2016). Do Universities Need Museums/Do Museums Need Universities? / The Antioch Review, Vol. 74, No. 2, The Future of Museums: Challenges and Solutions (Spring), P. 309-323 
[7] Documenting the theatrical heritage: an international science conference: On the 90th anniversary of the Russian state art library: lectures, papers, publications (2013) / Russian state art library; [Comp. by A. A. Kolganova]. Moscow: Novoe Izdatelstvo, $424 \mathrm{p}$.

[8] Dukelskii, V.Iu. (1986). Terminological problems of the theory of museum item./ In comp. Terminological problems of museology, Moscow, p. 27-35

[9] Expansion of the educational space. / Educational programs / (1999). Ed. by O. E. Lebedev, Saint Petersburg. P. 50-60.

[10] Federal Targeted Program "Culture of Russia (2012-2018)" [Electronic resource]. - Available at: http://fcpkultura.ru

[11] Galkina, T.V. (2012). Basic principles of classification of museum education forms in Russian museums. / Matters of museology, (4), P.144-153

[12] Ganshina, G.V, Gribkova, G.I., Umerkaeva, S.Sh.(2016). Diversification of higher education in the conditions of the socio-cultural interaction of university and museum. / Social and cultural partnership: university-museum-library in the conditions of innovative development: a collective monograph. - Moscow: UTs Perspektiva, P. 196-209

[13] Gibbons,W. (2013). Building the Operatic Museum: Eighteenth-Century Opera in Fin-de-Siècle Paris. Boydell \& Brewer, University of Rochester Press. 90 p. / Museums (P. 8-20)

[14] State programme of Moscow city "Culture of Moscow for 2012-2018" [Electronic resource]. - Available at: http://kultura.mos.ru

[15] Heilbrun,. J. (1993). Innovation in art, innovation in technology, and the future of the high arts.. / Journal of Cultural Economics, Vol. 17, No. 1 (June), P. 89-98

[16] History of theatre in the archival and book collections: The ninth academic readings Theatrical book between the past and the future: lectures, papers (2011) / Russian state art library; [ed.-comp. A. A. Kolganova]. - Moscow: Tri Kvadrata, 300 p.

[17] History of theater libraries and collections: The fifth academic readings (2003) / Theatrical book between the past and the future: lectures, papers / [ed.-comp. A. A. Kolganova]. - Moscow: Fair-Press, 268 p

[18] Hughes, C. (1998). Theater and Controversy in Museums./ The Journal of Museum Education, Vol. 23, No. 3, Too Hot to Handle? Museums and Controversy, P. 13-15

[19] Kagan, M.S.(1944). Museum in the system of culture. / Matters of art history. No. 4. P.16-31.

[20] Kaitandzhan, M.G.(2016). Theatre museum of Moscow as potential partners of universities in preparation of students to dramatized forms of cultural and leisure activities / Social and cultural partnership: university-museum-library in the conditions of innovative development: a collective monograph. - Moscow: UTs Perspektiva, P. 100-109

[21] Khodetskii V.G., Kirsanova E. L.(2002)/ University museum and its educational role / Museum and student: a compilation of research papers. - Syktyvkar, P. 12-15.

[22] La Scala Theatre (Milan). Catalogue of the exhibition of theatrical paintings.(1964) / Ed. by E. Rava; Russian translation by Ch. Gianluigi. - Moscow: $106 \mathrm{p}$

[23] Loukaitou-Sideris, A., Grodach,.C.(2004).Celebrating the "Other": A Study of the Mission, Scope, and Roles of Ethnic Museums in Los Angeles / The Public Historian, Vol.
26, No. 4, P. 49-71

[24] Mintz, N.V.(1989)/ Theatre collections of France / N. V. Mints. - Moscow: Iskusstvo, $446 \mathrm{p}$.

[25] Memorial apartment of G. S. Ulanova (Moscow). Branch of A.A. Bakhrushin State Central Theatre Museum: informational publication (2009)/ text author P. V. Doroshenko. - Moscow, A.A. Bakhrushin State Central Theatre Museum, $16 \mathrm{p}$.

[26] Museum of theater and music (Tallinn): [Guide] (1975) / Ministry of culture of the ESSR - Tallinn, $22 \mathrm{p}$.

[27] Museum of theatrical and musical art: a chronicle of the century, 1908-2008 (2008) / [aut.-comp.: L. P. Bastrakova et al.]. - Saint Petersburg: Art Deco, 246 p.

[28] Nikishin, N. A. (1991). "Museum language" as a universal modeling system of museum activity / Problems of cultural communication in museum activity, Moscow, 1989; Museums of the World, Moscow, P. 7-15

[29] Oestreicher, L.(2990).Museum Theater: Coming of Age / The Journal of Museum Education, Vol. 15, No. 2, Museum Theater (Spring-Summer), P. 4-5

[30] Pitman, B. (1999). Muses, Museums, and Memories. / Daedalus, Vol. 128, No. 3, America's Museums (Summer), P. 1-31

[31] Shiakhtina, L.M. (2011) Modern museum: ideas and realities. / Matters of museology 2(4), P. 14-19

[32] Sidharta, A.(1994). Visual Elements of Exhibitions. / The Journal of Museum Education, Vol. 19, No. 1, Museum Education in Europe: Societies in Transition Part 1 (Winter), P. 20-21

[33] Stoliarov, B.A. (2001). Museum education: the past and the present / Narodnoe Obrazovanie, No. 5, P. 177-182

[34] Taran, A.V.(2005). University museums of Russia: the past, the present and the future. / Cultural observatory: the observer magazine. No. 2, P. 64-71

[35] The Theatre museum: Victoria a. Albert museum(1978) / Comp. by Alexander Schouvaloff ; Pref. a. introd. by Catherine Haill. - London: Scala books, 144 p.

[36] Theatre museum [masterpieces of the collection: guide] (2017) / Saint Petersburg state Museum of theatrical and musical art, Foundation for the development of the Museum of theatrical and musical art, the Delzell Charity; [authors-compilers: N. I. Weinberg et al.]. - Saint Petersburg: Museum of theatrical and musical art, $36 \mathrm{p}$

[37] Troianskaia, S. L.(2007). Museum education and its educational opportunities in the development of general cultural competence. Izhevsk., $139 \mathrm{p}$

[38] Umerkaeva, S. Sh. (2017). Museum and university: relevent problems of socio-cultural interaction. / Interactive science. No. 6(16), P.35-37

[39] Vyshina, G. V.(1999). Museum education as the direction of development of system of additional education. Dissertation. Lipetsk, 202 p.

[40] Zhukov, R. F.(2001). Ways of development of active methods of education in the university. In comp. of scientific works Technology of acmeological methods of education. / Ed. R. F. Zhukov. - Saint Petersburg: Spbgieu, $160 \mathrm{p}$. 